\title{
Impact of E-Banking on the Development of Banking Sector in Nigeria
}

\author{
Dr. Abbas Umar Ibrahim ${ }^{1 *}$, Dr. Cross Ogohi Daniel ${ }^{2}$

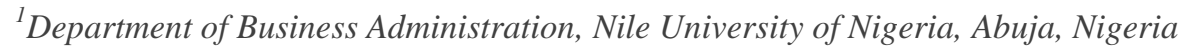 \\ ${ }^{2}$ Departments of Public Administration/Banking and Finance, Nile University of Nigeria, Abuja, Nigeria \\ *Corresponding Author: Dr. Abbas Umar Ibrahim, Department of Business Administration, Nile \\ University of Nigeria, Abuja, Nigeria
}

\begin{abstract}
Automation through computer network has become a necessity in the world of banking today thus this research work sets out to investigate the impact of electronic banking in the development of Nigerian banking sector. Electronic banking has become a very important and indispensable tool for the present survival and growth of financial institutions considering the dramatic increase in the number of banks in Nigeria in recent years. The methodology of the study as discussed in Chapter three it comprises of the research and questionnaire design, data collection and data analysis techniques. The Main research question, Research questions and Questions were used in the course of this research work. After a thorough investigation, it was discovered that electronic banking has both negative and positive impact in the Nigerian banking sector. While it has greatly improved service delivery on the positive angle but on the negative side, it is prone to electronic fraud and unauthorized access to information.
\end{abstract}

Keywords: E-banking, Development, and banking

\section{INTRODUCTION}

The new millennium brought with it new possibilities in terms of information access and availability simultaneously, introducing new challenges in protecting sensitive information from some eyes while making it available to others. Today's business environment is extremely dynamic and experience rapid changes as a result of technological improvement, increased awareness and demands Banks to serve their customers electronically. Banks have traditionally been in the forefront of harnessing technology to improve their products and services.

The Banking industry of the 21st century operates in a complex and competitive environment characterized by these changing conditions and highly unpredictable economic climate. Information and Communication Technology (ICT) is at the centre of this global change curve of E-banking System in Nigeria today. Assert that they have over the time, been using electronic and telecommunication networks for delivering a wide range of value added products and services, managers in Banking industry in Nigeria cannot ignore Information Systems because they play a critical impact in current Banking system, they point out that the entire cash flow of most fortune Banks are linked to Information System.

In this work study, I intend to trace the historical development of competition in the Nigeria banking sector by considering the services rendered by banks especially between the pre and the post consolidation era. There is a paradigms shift in the types of services rendered by the Nigeria banks shortly after consolidations. The competition witness among banks has been a factor in relation to the services delivery. The era of universal banking became operational and more visible after the N25billion minimum capital base for Nigerian banks. The banking reform which stipulated a minimum capital of N25billion in 2004 brought about merger and acquisition, raising capital from the capital market, as well as foreign direct investment into the banking sectors. This made them to be operating between N50 and N100 billion capital bases. A good number of them became diversified in their service delivery and move on to become a global player.

However, some observers still believes that there are factors that influence bank customers ${ }^{\text {ee }}$ preferences. This study would look critically at banking services delivery in the financial sector and 
the factors that influence customer's patronage of a bank.in Nigeria. I would also consider the factors influencing bank consolidation on the services render by banks to their customers and how it has translated into success story to some of the banks. The bank is a financial institution set-up purposely for safekeeping of money, valuable goods and documents like wills and gold. It collects surplus funds from the general public, safeguards them and makes them available to the true owner when required and loans out fund (at interest) to those who need them (Obi 2002). In a nutshell, a bank is an institution engaged in safekeeping of monies, issuing drafts, and giving loans on interest to those who are in need of such.

The statutory functions of bank become more complex because of the complex nature of business activities and the increase in demand and number of customers, as well as the competitive nature of banking industry (Irechukwu, 2000). This made the bank to look inward to customer oriented services which will enhance efficient and effective customer services, Again, the business of banking is no longer perceived as merely the generation of deposit, liabilities and creation of liquid assets, but rather the generation, storage, manipulation, communication and application of financial information.

E- Banking is a process of transacting banking operations electronically. It is a process of using electronic devices in carrying out banking operations. E banking does away with most visits to the bank. It is a state-of-the-art-service that is just beginning to take off among banking customers especially in Nigeria. Indeed E-banking has the major potential for future development as it allows customers to do most of the things they do at the bank like make balance enquiries, payment, transfer of funds, pay bills over the internet. It also offers banking services outside of normal opening hours. In fact, it has effectively "opened" banks for business twenty-four hours a day, seven days a week (Rubino 2000).

With the proliferation of the internet, coupled with the world increasingly addicting to e-business, the trend of cash transactions is now giving way to electronic payment system. This growing acceptance of the digital lifestyle, as stated in Salehi and Alipour (2010), has brought a significant transformation in customers' expectations from their financial service providers. According to Offei and Nuamah (2016), customers are now seeking for a faster and convenient technology with more rewarding banking experience.

Perceived Usefulness (PU) and Perceived Ease of Use (PEOU) are two factors mentioned in Davis's Technology Acceptance Model (TAM) that influences users' decision to use a particular technology system (Surendran, 2012), users will eventually lose interest in e-banking if they feel that it is no longer useful even if the system is somewhat easy to handle (Obiri et al., 2013). Therefore banks that fail to respond to the emergence of e-banking in the market are likely to lose their customers (Salehi and Alipour, 2010); Lee (2009) stressed that its adoption seem not to be yielding the anticipated results, thereby creating a gap between the actual returns and its proposed objectives.

Besides the high cost of transactions and epileptic network connections associated with e-banking system in Nigeria, the introduction of e-banking into banking operations brought an increase both in the volume of deposits, as well as fraudulent practices (Agwu and Carter, 2014). Even with the aim of using it to decongest banking halls, these halls are most of the time still full with customers. If these situations are not dealt with accordingly, it could result into some negative consequences since the more active customers are with their electronic transactions the more profitable it is for the banks and a dis-satisfied customer leaves an organization with negative word of mouth publicities about the organization (Agwu and Carter, 2014).

According to Agwu and Murray (2014), this optimal integration of all the activities of a bank through the deployment of modern information technology is based on bank process and in accordance with the organizational structure of banks. Therefore, e-banking employs the use of information communication technology to drive banking business for immediate and future goals, hence for the banks, it is a strategic weapon used in achieving competitive advantage and increasing their market share (Agwu and Murray, 2015).

\section{Statement of the Problem}

E-banking is a driving force that is changing the landscape of the banking environment fundamentally towards a more competitive industry. E-banking has blurred the boundaries between different financial institutions, enabled new financial products and services, and made existing financial services available in different package, but the influences of e-banking go far beyond this. 
The developments in e-banking together with other financial innovativeness are constantly bringing new challenges to finance theory and changing people's understanding of the financial system. It is not surprising that in the application of e-banking in Nigeria, the financial institutions have to face its problems: - Communication over the internet is insecure and often congested, The financial institutions would also have to contend with other internet challenges including insecurity, quality of services and some aberrations in electronic finance and Besides, the existing banking environment also possesses some challenges to the smooth operations of e-banking in Nigeria. Some of these operational challenges include; Epileptic power supply, dominance of cash transaction in the economy, low level of awareness among Nigerian etc. The thrust of this research work shall be to examine the impact of e-banking on the development of Nigerian banking sector.

\section{OBJECTIVE OF THE STUDY}

The general purpose of the study is to examine the impact of e-banking on the development of Nigeria banking sector. Specifically, the objectives aimed are as follows:

- To evaluate the prospects of e-banking in Nigerian banking environment.

- To examine the impact of e-banking on the operations of financial institutions

\section{RESEARCH HYPOTHESES}

The following alternate hypotheses will be used for the study:

$\mathrm{H}_{1}$ : There are prospects of e-banking in Nigeria banking environment.

$\mathrm{H}_{2}$ : There are impacts of e-banking on the operation of financial institutions

\section{LITERATURE REVIEW}

\subsection{Conceptual Framework on E-Banking}

Anyanwuocha (2004) defined bank as a financial institution that provides banking and other financial services. Bank is generally understood as an institution that holds a banking license. The banking license is granted by financial supervisor authorities to conduct the most fundamental banking services such as accepting deposits and making loans available to their numerous customers.

E-banking is a kind of banking that involves electronic form of money transaction. Here banking services are fully automated such that transactions are concluded in a jiffy. It involves the use of computer network in dispensing cash and transfers of fund. The primary objectives are to replace intensive labour operation and thus help reduce the waiting time of customers. For now in Nigeria, ebanking is limited to the automated teller machine and electronic funds transfer. It also includes electronic devices such as SQL and MICR. The emergence of e-banking products brings to an end the era of mechanical and laborious banking.

E-banking means not only electronic production, like, for instance, opening a letter of credit, but also the customer requests the services by electronic means and that the bank supplies it the very same way. In banking operations, technical change encompasses the marketing and distribution function in addition to production. Having defined e-banking, we now in the next section consider various ebanking products existing within and outside the Nigerian's Financial System.

Like many other sectors, banking has been suffering changes due to development and improvements in ICT (Onodugo, 2015), which has been a useful tool to follow market demands and practices. This development of new technologies has been causing a huge impact on organizations in terms of management and control, marketing and research, operations and decision making (Onodugo, 2015). Banking technology is not a new topic. It has been a constant presence in the literature since the late 1980s and early 1990s.

E-banking can be defined as a set of activities conducted from home instead of a physical bank location (Obiri et al, 2013). It is an "umbrella term for the process by which a customer may perform banking transactions electronically without visiting a bricks-andmortar institution. E-banking can be also referred to as online banking, cyber banking, virtual banking and net banking (Obiri et al, 2013). Moreover, there are three types of e-banking: internet banking, phone banking and mobile banking, that differ in terms of distribution channel, internet, phone and mobile phone, respectively. 
According to Onodugo (2015), e-banking is not something totally new. It started some time ago in the form of ATMs and telephone transactions. This first generation of solutions typically only allowed customers to view their statements online, conduct transfers between accounts and pay bills (Obiri et al, 2013). Nowadays, the amount of operations that can be carried out using e-banking services is far greater. Customers can use e-banking to: pay utility bills and insurance premiums; fund transferences; consult current account and savings balances; carryout mortgage payments; options subscriptions; book orders online; book flights and railway tickets; and, purchase products online.

\subsection{Impact of E-banking}

The emergence of e-banking in the Nigerian financial system is partly to keep pace with modern technologies applicable to modem banking. More importantly, it is being used as a competitive tool by banks. Conscious of the need to satisfy the sophisticated customers, banks introduced these products in order to reduce human errors. They also aim at reducing the waiting time of customers as well as reducing human labour and paper work involved before customers are attended to. So the immediate impact of ATM is that we should begin to see a substantial reduction in the queues that often develop at the bank counters. Banks would thereby have more time to devote to strategic planning thus increasing the efficiency of the average bank worker.

ATM customers now enjoy the benefit of banking, customers now enjoy 24 hours services, in which case weekend banking will be unnecessary as soon as ATM is able to accept deposits and give account balances. Also as more banks acquire ATM, we expected to see fewer bank customers holding on to large cash particularly at weekends. This would ultimately reduce the volume of money in circulation.

\subsection{Advantages of E-banking}

The transition to e-banking, as opined in Chemtai (2016) offers major opportunities in terms of competitive advantage. Specifically, it provides banks with the opportunity to develop a stronger and more durable business relationship with their customers. For instance, it makes access to finance from banks attractive with funds appearing to be much more available (Salehi and Alipour, 2010), and customers are given the opportunity to conduct banking transactions with great peace of mind and at their convenience (Offei and Nuamah-Gyambrah, 2016).

Before the introduction of e-banking, transactions took a lot of time to execute and this was tiring. Now, services are rendered quicker with transactions much more accurate hereby saving time, as well as reducing human errors and clerical overhead cost. Some other benefits derived from e-banking are increased customer satisfaction, expanded product offerings and extended geographic reach. These have helped to attract more customers since the level of satisfaction is high and also helped to conserve the energy of employees therefore giving them the opportunity to put in their best into the roles they have to play in the bank. The advantages of e-banking can thus be summarized into increased bank development (Chemtai, 2016), increased comfort and timesaving, quick and continuous access to information, better cash management (Salehi and Alipour, 2010) and improved customer experience (Onodugo, 2015).

\subsection{The Development of E-banking in Nigeria}

Banking services development in Nigeria as a side-line to other commercial activities of Elder Dempster Sector. According to available information, the first real bank in Nigeria was the African Banking Corporation founded in 1892. In 1894, Bank of British West African Banking Corporation which called the bank of West African on Nigeria's Independence and later called the Standard Bank of Nigeria Limited and subsequently changed its name to First Bank of Nigeria Ltd now Plc. had complete monopoly of business in the banking industry until the establishment in 1917 of the colonial bank. The Colonial Bank opened branches in Jos, Kano, Lagos and Port Harcourt. In 1952 the bank changed its name to Barclays Bank DCO and is now called Union Bank of Nigeria Plc.

Indigenous participation in the Banking Industry started in 1929 with the establishment of the Industrial and Commerce Bank by a group of Nigerian and Ghanaian Entrepreneurs. The Bank failed in 1930 due to inadequate capital, poor management, hostile and unfair competition from the foreign established banks. Undaunted by the failure of the first attempt at establishing an indigenous bank, another group of entrepreneurs, this time all Nigerians among whom were the late Dr. A. Maja, Chief 
T. A. Doherty and Late H. A. Subair established the Nigerian Merchant Bank in 1933. The bank was more successful than its predecessor, but like it, also failed in 1936.

Meanwhile the same group of indigenous pioneers in field of banking had established in 1993 the National Bank of Nigerian Limited, which was to make history by being the first indigenous bank to survive though with some few problems to the 1952 Banking Ordinance. The success of National Bank Limited through careful management by the Western Regional Government inspired other Nigerians to go into banking business and in 1945, Chief Okupe established the Agbonmagbe bank. As a private enterprise it thrived. It thus became the fourth indigenous bank to be established. It also survived though it ran into difficulties in 1967, it was saved by the Western Nigerian Development Corporation (WNDC), later IICC and now Odua Investment Corporation who took over its operations and changed its name to Wema Bank Limited. The Nigerian Penny Bank was the fifth indigenous bank to be established but it packed up operations with disastrous consequences to depositors soon after registration in 1946.

In 1946, Dr.Azikiwe established the Tinubu Bank to serve the Zik Group of the Companies, which was established in 1941 called Tinubu Properties Ltd. The name of the bank was changed to the African Continental Bank in 1947 with its first office in Yaba. In 1949, another foreign bank, British and French Bank was established. The bank was re-established in 1961 by a consortium of five foreign banks. Since then it has been known as the United Bank for African (UBA). In order to have further insight into the history and development of the Banking industry in Nigeria, from the establishment of the first in 1892 to date, it will be convenient to drive the period into three distinct eras.

\subsection{The Challenges and Limitations of E-banking}

Automation is very expensive venture more so in Nigeria where infrastructure and support facilities (like dedicated line called "lease lines" from NITEL) are virtually non-existent. It must be remembered that hardware cost represent only a fraction of the overall cost of an automation project. On the other hand potential benefits of automation are usually very subjective and not easily verified. Any recommendation therefore to automate must be very well thought out and the true impact of all expenditures involved in the automation plan must be clearly communicated to users. Management in the feasibility or other report presented for consideration. Automation also involves a lot of expenditures to retailer and customers who want to install personal computers. The cost consideration must include the following:

- Hardware -generators, air conditioning, communication equipment

- Software - operation system and application programs - Stationery

- Conversion

- Training - data processing staff, implementation staff and user staff

- Maintenance of both hardware and software's

And again, there is tendency to dorge the cost of keeping the system riming at all times and in an up to date fashion. Another challenges or limitation to e-banking in Nigeria is the official red-tapism in the banking system of operation. For instance, quite numbers of banks that render on-line-real-time services still maintain anachronistic policies such as not allowing cashiers to dispense across the counter, cash beyond a certain sum. In some banks a cashier cannot honour a cheque that is above S500 or S1, 000 without getting authorization or over-lapping of a supervisor. Consequently, long queues still thrive in such banks, rendering meaningless the computerization effort.

Furthermore, banks should be selective in the choice of candidates for ATM because fraud can easily be perpetrated through it. Such restriction is also 46 whatever you feed into the computer is what it rolls out (Garbage in, Garbage out) Though some errors are inadvertent, there are cases of wrong programming by operators with the intent to defraud. This again leads to the legal implications of electronic form of banking. Although customers are warned on the need to keep safe their ATM card and personal identification numbers, this is likely to be abused in future.

What therefore is the bank's legal position when a customer's account is debited in error and when a fraud is perpetrated on the account using ATM? In the first instance, when a customers' account is 
debited in error, the bank is at fault and it must take appropriate action to mitigate injuries that could be suffered by the customer. The other hand if a fraud is perpetrated without the knowledge of the customer this may involve the bank in unnecessary and avoidable litigation since such debits are difficult to prove.

\section{MeThOdOLOGY}

This study focuses on the impact of e-banking on the development of Nigerian banking sector. No doubt, it will be practically difficult to cover all organizations in this study. The scope covers a mortgage bank in Wuse, Abuja, namely Infinity Trust Mortgage bank.From a total of ninety two (92) copies of the questionnaire distributed to the respondents, eighty (80) copies representing $87 \%$ were duly completed and returned while (12) copies representing $13 \%$ were not returned. The questionnaire was designed in Likert scale format. The researchers conducted a pre-test on the questionnaire to ensure the validity of the instrument. Pearson product moment correlation coefficient was used to test the hypotheses

\section{TEST OF HYPOTHESES}

$\mathrm{H}_{\mathrm{I}}$ : There are prospects of e-banking in Nigeria banking environment.

$\mathrm{H}_{0}$ : There are no prospects of e-banking in Nigeria banking environment.

Table1. Table of correlation between effective e-banking and banking sector

\begin{tabular}{|l|l|l|l|}
\hline \multicolumn{2}{|c|}{ Correlations } & \multicolumn{1}{|c|}{ Effective e-banking } & \multicolumn{1}{|c|}{ level of banking sector } \\
\hline effective e-banking & Pearson Correlation & 1 & $.536^{* *}$ \\
& Sig. (2-tailed) & 200 & .000 \\
& $\mathrm{~N}$ & & 80 \\
\hline level of banking sector & Pearson Correlation & $.536^{* *}$ & 1 \\
& Sig. (2-tailed) & .000 & 200 \\
& $\mathrm{~N}$ & 80 & \\
\hline
\end{tabular}

**. Correlation is significant at the 0.01 level (2-tailed).

According to above calculations it is observed that amount of correlation coefficient between level of development and effective banking sector is equal to 53.6 per cent and considering that a significant level is less than $5 \%$. Then we can say that there is a positive relationship between effective e-banking and banking sector. This implies that one percent increase in effective e-banking will lead to $53.6 \%$ increase in level of banking sector

Table2. Regression analysis test of level of banking sector and e-banking

Model Summary

\begin{tabular}{|c|l|l|l|l|}
\hline Model & \multicolumn{1}{|c|}{ R } & \multicolumn{1}{c|}{ R Square } & Adjusted R Square & Std. Error of the Estimate \\
\hline 1 & $.965^{\mathrm{a}}$ & .716 & .586 & 3.79952 \\
\hline
\end{tabular}

a. Predictors: (Constant), effective e-banking

Regression coefficient of $\mathrm{R}=.965$ or $96.5 \%$ indicate that relationship exist between independent variables and dependent variable. The coefficient of determination $\mathrm{R}^{2}=0.716$ which show that $71.6 \%$ of variation in level of banking sector explained by effective e-banking. The adjusted R-square in the table shows that the dependent variable, (level of banking sector) is affected by $58.6 \%$ by independent variable (effective e-banking). It shows that effective e-banking is responsible for level of development for the banking sector.

Table3. Coefficients ${ }^{a}$

\begin{tabular}{|l|l|l|l|c|c|}
\hline \multirow{2}{*}{ Model } & \multicolumn{2}{|c|}{ Unstandardized Coefficients } & Standardized Coefficients & \multirow{2}{*}{ t } & \multirow{2}{*}{ Sig. } \\
\cline { 2 - 5 } & \multicolumn{1}{|c|}{ B } & Std. Error & & & \\
\hline 1 & 12.310 & .901 & & 13.656 & .002 \\
effective e-banking & 1.056 & .085 & .536 & 12.426 & .000 \\
\hline
\end{tabular}

a. Dependent Variable: level of banking sector

The coefficient of determination for effective e-banking is positive (1.056) and is highly significant (0.001) in ensuring level of development. The p-value of 0.000 is less than the t-statistic value of 
12.426 and the standard error value of 0.085 . This implies that a unit increase in effective e-banking will lead to 1.056 increases in level of development. Therefore, the null hypothesis is rejected and alternative hypothesis accepted that there is a relationship between the effective e-bankingon the development of Nigeria and the level of banking sector.

\section{Hypothesis two}

$\mathrm{H}_{2}$ : There are impacts of electronic banking on the operation of financial institutions

$\mathrm{H}_{0}$ : There are no impacts of electronic banking on the operation of financial institutions

Table4. Table of correlation between e-banking and improving in the banking sector

\begin{tabular}{|l|l|l|l|}
\hline \multicolumn{2}{|c|}{ Correlations } & e-banking & improving the banking sector \\
\hline \multirow{3}{*}{ e-banking } & Pearson Correlation & 1 & $.473^{* *}$ \\
& Sig. (2-tailed) & 200 & .000 \\
& $\mathrm{~N}$ & & 80 \\
\hline $\begin{array}{l}\text { improving the banking } \\
\text { sector }\end{array}$ & Pearson Correlation & $.473^{* *}$ & 1 \\
& Sig. (2-tailed) & .000 & 200 \\
& $\mathrm{~N}$ & 80 & \\
\hline
\end{tabular}

**. Correlation is significant at the 0.01 level (2-tailed).

According to above calculations is observed that amount of correlation coefficient between e-banking and improving in the banking sector is equal to 47.3 per cent and considering that a significant level is less than 5\%. Then we can say that there is a positive relationship between e-banking and improving in the banking sector. This implies that one percent increase in e-banking will lead to $47.3 \%$ increase in improving in the banking sector

Table5. Regression analysis test of e-banking and development in Nigeria

\section{Model Summary}

\begin{tabular}{|c|c|c|c|c|}
\hline \multicolumn{1}{|c|}{ Model } & R & R Square & Adjusted R Square & Std. Error of the Estimate \\
\hline 1 & $.773^{\mathrm{a}}$ & .624 & .722 & 3.96426 \\
\hline
\end{tabular}

a. Predictors: (Constant), e-banking

Regression coefficient of $\mathrm{R}=.773$ or $77.3 \%$ indicate that relationship exist between independent variables and dependent variable. The coefficient of determination $\mathrm{R}^{2}=0.624$ which show that $62.4 \%$ of variation in improving the banking sector is explained by e-banking. The adjusted R-square in the table shows that the dependent variable, (improving the banking sector) is affected by $72.2 \%$ by independent variable (e-banking). It shows that there are positive impacts of e-banking on improving the banking sector.

Table6. Coefficients ${ }^{a}$

\begin{tabular}{|l|l|l|l|c|c|}
\hline \multirow{2}{*}{ Model } & \multicolumn{2}{|c|}{ Unstandardized Coefficients } & \multicolumn{1}{|c|}{ Standardized Coefficients } & \multirow{2}{*}{ t } & \multirow{2}{*}{ Sig. } \\
\cline { 2 - 6 } & \multicolumn{1}{|c|}{ B } & Std. Error & & & \\
\hline 1 (Constant) & 15.036 & .806 & & 18.644 & .000 \\
E-banking & 1.319 & .125 & .473 & 10.520 & .000 \\
\hline
\end{tabular}

a. Dependent Variable: improving the banking sector

The coefficient of determination for e-banking is positive (1.319) and is highly significant (0.000) in improving in the banking sector. The p-value of 0.000 is less than the t-statistic value of 10.520 and the standard error value of 0.125. This implies that a unit increase in e-banking will lead to 1.319 increases in improving in the banking sector. Therefore, the null hypothesis is rejected and alternative hypothesis that there are positive impacts of e-bankingon improving in the banking sector.

\section{Conclusions}

Based on the findings made, the following conclusions were made:

There is a great increase in the numbers of commercial bank customers with the adoption of e banking services. At least the quality of services rendered to customers has improved greatly. Customers are satisfied with some of the e banking service offered to bank customers; however, a lot needs to be done to improve the customer service in the Country. There are benefits that customers accrued from 
the utilization of e-banking by commercial banks in Nigeria. This has promoted social, economic, and political development of the state.

Commercial banks were faced with a lot of problems in the provision of e-banking to customers in the state. These problems needed to be tackled in order to enhance effective and efficient customer services. Finally, commercial banks would grow tremendously, if the proprietors can invest more on the information technology to boast their daily banking operations.

\section{RECOMMENDATIONS}

The researcher undertook an empirical investigation of both the positive and negative effect of ebanking in the Nigerian financial system and therefore has drawn the following recommendations. The government should relax further its regulatory hold on the financial system and not partial deregulation of the system widely believed to be the case right now. Though this is not a sufficient condition, it is necessary condition for overall efficiency of the system.

Telecommunication needs to be improved to facilitate easy data communication network for banks and other financial institutions as well as other organisations. Thus the electronic tellers and electronic funds transfer facilities will greatly improve. The customers must be educated on the effective use of their cards and the need to ensure confidentiality of their personal identification numbers (PIN). The advent of electronic automation through computer network has however had its peculiar problem, which had hitherto been linked only to the manual system. These usually manifest themselves in the form of software fraud.

Most of the irregularities result from illegal access to the electronic system, authorized access to specific modules $\mathbf{J}$ functions within an application software, intentional alteration of data or the denial of since to authorized personnel. This problem could be addressed by the implementation of an appropriate audit and security mechanisms for processing these applications. These could be achieved by instituting software control by defining the hierarchy of personnel that have access to the system. Also all access to the system should be logged automatically to a control file and printed on a regular basis for the purpose of effective control.

Finally, a group of banks can come together and implement an integrated ATM system. They can also jointly implement shared computer system and network, credit card system and electronic funds transfer facilities as is the case in the United States of America and some other developed countries of the world.

Efforts to improve banking services (in Nigeria) recently got a boost as 30 banks were selected for the Nigerian Automated Clearing System (NACS). The system is an on-line service designed to facilitate the clearing of cheques, credit instruments as well as the payment and settlement of inter-bank transactions. When operational, the NACS will replace the current manual.

\section{REFERENCES}

[1] Agwu ME, Murray PJ (2014). Drivers and inhibitors to e-Commerce adoption among SMEs in Nigeria; Journal of Emerging Trends in Computing and Information Sciences, Vol. 5, No.3 March 2014 ISSN 2079-8407, pp. 192-199 Available at: http://www.cisjournal.org/

[2] Agwu ME, Carter AL (2014) Mobile phone banking in Nigeria: benefits, problems and prospects. International Journal of Business Comminucation, 3(6): 50-70

[3] Agwu ME, Murray PJ (2015) Empirical study of barriers to electronic commerce adoption by Small and Medium scale businesses in Nigeria. International Journal of Innovation in the Digital Economy, and TPB with perceived risk and perceived benefit, Electronic Commerce Research and Applications, Forthcoming.

[4] Anyanwuocha, R.A.I (2004) Economics for the Certificate year, Onitsha, Africana-First Publishers Limited

[5] Chemtai F (2016). The effects of electronic plastic cards on the firm's competitive advantage: A case of selected commercial banks in Eldoret town, Kenya. International Journal of Science Education Studies 2(2), 29-39

[6] Ezeoha A. E. (2006). Regulating internet banking in Nigeria, Problem and challenges- Part-2 Journal of Internet Banking, Commer. 11(1)

[7] Irechukwu, G. (2000). Enhancing operation through appropriate information technology: In Evans Woherein (ed) information Technology in Nigeria banking industry, Ibadan, spectrum Books Ltd. 
[8] Obiri-Yeboah K, Kyere-Djan R, Kwarteng KA (2013). The role of information technology on banking service delivery: A perspective from customers in Ghana. Intern. J. Innov. Res. Manag. 2 (6), 1-12.

[9] Offei MO, Nuamah-Gyambrah K (2016). The contribution of electronic banking to customer satisfaction: A case of GCB bank limited- Koforidua. Intern. J. Manag. Inform. Technol. 8(1), 1-11.

[10] Onodugo IC (2015). Overview of electronic banking in Nigeria Intern. J. Multidiscipl. Res. Dev. 2 (7), 336 $-342$

[11] Rubino, G. (2000) getting and keeping online customers. If you build it will they come Bank marketing, Washington.

[12] Salehi M, Alipour M (2010). E-banking in emerging economy: Empirical evidence of Iran. Intern. J. Econ. Finan. 2(1), 201-209 satisfaction and loyalty; evidence from Finland", Intern.J. Electr. Finan. 3(3): 253269

[13] Surendran P (2012). Technology acceptance model: A survey of literature. Intern. J. Bus. Soc. Res. 2(4), $175-178$

Citation: Dr. Abbas Umar Ibrahim, Dr. Cross Ogohi Daniel. "Impact of E-Banking on the Development of Banking Sector in Nigeria" International Journal of Managerial Studies and Research (IJMSR), vol 7, no. 2, 2019, pp. 19-27. doi: http://dx.doi.org/10.20431/2349-0349.0702004.

Copyright: () 2019 Authors. This is an open-access article distributed under the terms of the Creative Commons Attribution License, which permits unrestricted use, distribution, and reproduction in any medium, provided the original author and source are credited. 